\title{
Studies on Variability, Heritability and Genetic Advance for Yield Attributing Traits in Brinjal (Solanum melongena L.) for Two Different Seasons
}

\author{
Priyanka Verma*, M.L. Kushwaha and Ankit Panchbhaiya \\ Department of Vegetable Science, Govind Ballabh Pant University of Agriculture and \\ Technology, Pantnagar (Uttarakhand), India \\ *Corresponding author
}

A B S T R A C T

\section{Keywords \\ Brinjal, Genetic variability, Heritability, GCV, Genetic advance as a percent of mean and PCV \\ Article Info \\ Accepted: \\ 10 August 2018 Available Online: 10 September 2018}

The present experiment was laid down in randomized block design in two different environments (E1 and E2) with the objective to assess the magnitude of genetic variability, heritability and genetic advance among 18 yield attributing traits in brinjal. The analysis of variance revealed that significant genetic differences were present among the brinjal genotypes representing the existence of significant amount of variability widening the greater scope for the improvement of concerned characters through selection. A moderate to wide range of mean values among the genotypes for different characters were observed. Moderate to high genotypic coefficient of variation together with moderate to high heritability and genetic advance as per cent of mean was reported for majority of the characters under study except days to 50 percent flowering, number of primary branches, fruit diameter and days to first fruiting in E2 season which indicated predominant role of additive genetic component in the expression of these traits arising a chance of genetic improvement through phenotypic selection.

\section{Introduction}

Brinjal (Solanum melongena L.) is one of the most important and popular solanaceous vegetable crops of India. Easy cultivation, year round availability, moderate to high yield and consumption in varieties of ways like as a vegetable, salad, bhaji, bhartha, chatni, pickles etc., has made brinjal the king of vegetables in India. The ethno-botanical history of brinjal has been quite fascinating which has indicated that it has been used for vegetable, medicinal and ornamental purposes since ancient time in
India. The $21^{\text {st }}$ century begins new vistas regarding the health value of brinjal, which is mainly due to its phenolics, glycoalkaloids, amide and anthocyanine content generally present in the peel of brinjal fruits. It is a rich source of vitamin A, B1, B6 and trace amount of micro nutrient like $\mathrm{Cu}, \mathrm{Mn}, \mathrm{Mg}, \mathrm{K}$ (Chen and $\mathrm{Li}, 1996)$ and its fruits are mainly used to cure diabetes (Choudhary, 1976), toothache (Chen and $\mathrm{Li}, 1996$ ), liver complaints and possess antioxidant and anti-cancer activities due to the presence of anthocyanin and polyphenol compound (Sato et al., 2011). 
Brinjal can be grown in wide range of agroclimatic zones round the year which provides us a great opportunity to exploit its full potential on condition of its tremendous scope of crop improvement. Planning and implementing of any breeding programme for the improvement of the various quantitative attributes of crop depend upon the extent and magnitude of genetic variability offered in the population. Variation is the secret of success in plant breeding program because it widens the scope of selection. The genetic facts are inferred from observations on phenotypes. Since phenotype is an artifact of the joint effects of genotype and environment, nongenetic part exerts large influence on genetic variability.

The exploitable variability is, therefore required to be judged through various genetic parameters like coefficient of variation at phenotypic and genotypic level, heritability and genetic advance. The estimates of heritability serves as a useful guide for the breeder as it enable them to understand the proportion of variation is due to genotypic effect or additive effect and provide the correct indication of the amount of improvement achieved through selection whereas, high heritability along with high genetic advance as a percent of mean is an indication of more additive gene action (Panse, 1957). Most of the local varieties which are grown by the farmers of India have not been fully utilized in any genetic improvement programs so far, on scientific line. Hence, the present study was under taken with an objective of studying the variability, heritability and genetic advance in different genotypes of brinjal, which can be utilized in future crop improvement programmes.

\section{Materials and Methods}

By taking 36 genotypes of brinjal, the present investigation was carried out at Vegetable research centre of G. B. Pant University of agriculture and technology during autumn winter (E1) and spring - summer (E2) season of 2017-18. The experiment was laid out in Randomized block design in which genotypes were arranged in three replication, each replication containing 36 treatments. The genotypes were studied for 18 yield attributing traits viz., days to first flowering, days to 50 percent flowering, days to first fruiting, number of primary branches, plant height $(\mathrm{cm})$, fruit length $(\mathrm{cm})$, fruit diameter $(\mathrm{cm})$, fruit index, average fruit weight $(\mathrm{g})$, number of healthy fruits per plant, number of infested fruits per plant, total number of fruits per plant, percent of shoot and fruit borer incidence, weight of healthy fruits per plant, weight of infested fruits per plant, total yield per plant $(\mathrm{kg})$, fruit yield per hectare $(\mathrm{q} / \mathrm{hac})$ and 100 seed weight (g) in both E1 and E2 seasons The analysis of variance was carried out as per methods suggested by Panse and Sukhatme (1967).

Methods given by Burton and De Vane (1953) were used to determine the genotypic coefficient of variation (GCV) and phenotypic coefficient of variation (PCV). Whereas, heritability (broad sense) and genetic advance as per cent of mean was computed as per Weber and Moorthy (1952) and Johnson et al., (1955), respectively.

\section{Results and Discussion}

The analysis of variance signifies that the mean sum of square due to treatment was found highly significant for all the yield attributing traits studied in both the E1 and E2 seasons at $1 \%$ and $5 \%$ level of significance. The significant difference among all the traits indicates the existence of sufficient amount of genetic variability, offering the good opportunity for the improvement of various economic traits in brinjal as presented in Table 1 and 2. The results are in consonance with 
Chourasia and Shree (2012), Shekar et al., (2012), Nayak and Nagre (2013), Madavi et al., (2015), Mohammad et al., (2015), Vidya and Kumar (2015), Reshmika et al., (2015), Pujer et al., (2017), Ravali et al., (2017), Tripathy et al., (2017) and Tirkey et al., (2018).

Variability refers to the presence of differences among the individuals of a population which is essential for wider adaptability and resistance to biotic and a biotic factors and hence, an insight into the magnitude of genetic variability present in a population is of paramount important to a plant breeder for starting a judicious breeding programme.

The extent of genetic variation can be judged by both the estimation of phenotypic coefficient of variation (PCV) and genotypic coefficient of variation (GCV). The estimates of phenotypic coefficient of variation (PCV), genotypic coefficient of variation (GCV), heritability in broad sense and genetic advance as a percent of mean for eighteen yield attributing traits in E1 and E2 season are presented in Table 3 and 4.

Assessment of variability parameters revealed that there is lot of variation present among the genotypes studied. In general, the value of phenotypic coefficient of variation (PCV) was higher than the genotypic coefficient of variation $(\mathrm{GCV})$ for all the characters studied in the present study, indicating the considerable influence of environmental factors on the performance of genotypes for different characters. Similar results were also reported in brinjal by Nayak and Nagre (2013), Patel et al., (2015) and Tripathy et al., (2017).

Among 36 genotypes of brinjal, highest GCV and PCV estimate were received for most of the traits viz., fruit index (69.087 and 71.989), weight of infested fruits per plant (48.738 and 51.07), number of healthy fruits per plant (45.12 and 48.46), number of infested fruits per plant (41.68 and 46.61), weight of healthy fruits per plant (41.583 and 42.661), fruit length (37.99 and 39.19), percent of shoot and fruits borer incidence (39.630 and 42.751), total number of fruits per plant (38.28 and 40.03), fruit yield per hectare (33.97 and $37.970)$, total yield per plant (32.481 and 36.578), fruit diameter (27.55 and 31.46), 100 seed weight (24.935 and 26.193) and average fruit weight (23.34 and 23.50) in E1 season. Whereas in E2 season, high GCV and PCV estimates were observed for fruit index (56.078 ad 56.078), number of healthy fruits per plant(47.961 and 48.75), number of infested fruits per plant (46.961 and 48.036), total number of fruits per plant (44.993 and 46.824), average fruit weight (38.436 and 38.81), fruit length (37.96 and 39.512), percent of shoot and fruit borer incidence (31.614 and 34.912), fruit diameter (30.772 and 35.688), weight of healthy fruits per plant (29.217 and 30.380), weight of infested fruits per plant (29.292 and 29.651), 100 seed weight (25.779 and 26992), fruit yield per hectare (24.35 and 25.61), total yield per plant (24.302 and 25.704) and number of primary branches (22.781 and 26.350). The higher values of PCV and GCV for the above traits signifies there maximum contribution towards genetic variability and thereby suggesting that the parents chosen on the basis of these characters may be utilized in further crossing programme for obtaining good transgressive segregants. The results of the present investigation agreed with the finding of Ansari et al., (2011), Shekar et al., (2012), Balaji et al., (2013), Singh et al., (2013a), Kumar et al., (2013b), Chaudhary and Kumar (2014), Mili et al., (2014), Gavade and Ghadage (2015), Madhavi et al., (2015), Patel et al., (2015), Shende et al., (2014),Vidya and Kumar (2015), Ravali et al., (2017), Sujin et al., (2017). 
Table.1 Analysis of variance for different yield attributing traits in brinjal for E1 season

\begin{tabular}{|c|c|c|c|c|}
\hline \multirow[t]{3}{*}{ S. $\mathbf{N}$. } & \multirow[t]{3}{*}{ Characters } & \multicolumn{3}{|c|}{ Mean sum of squares } \\
\hline & & Replication & Genotype & Error \\
\hline & & 2 & 35 & 70 \\
\hline 1 & Days to first flowering & 1.878 & $69.355 * *$ & 1.356 \\
\hline 2 & Days to 50 percent flowering & 2.083 & $91.581 * *$ & 1.901 \\
\hline 3 & Days to first fruiting & 0.562 & $91.996 * *$ & 2.901 \\
\hline 4 & No. of Primary branches & 0.745 & $13.420 * *$ & 1.35 \\
\hline 5 & Plant height $(\mathrm{cm})$ & 128.823 & $513.424 * *$ & 28.371 \\
\hline 6 & Fruit length $(\mathrm{cm})$ & 1.617 & $89.982 * *$ & 1.876 \\
\hline 7 & Fruit diameter $(\mathrm{cm}$ & 0.166 & $7.133 * *$ & 0.655 \\
\hline 8 & Fruit index & 0.122 & $14.496 * *$ & 0.403 \\
\hline 9 & Average fruit weight (g) & 3.865 & $1021.634 * *$ & 4.794 \\
\hline 10 & No. of healthy fruits per plant & 15.176 & $98.013 * *$ & 4.907 \\
\hline 11 & No. of infested fruit per plant & 0.121 & $17.040 * *$ & 1.314 \\
\hline 12 & Total no. of fruit per plant & 14.858 & $144.376^{* *}$ & 4.358 \\
\hline 13 & Percent of shoot and fruit borer incidence & 5.022 & $535.277 * *$ & 27.692 \\
\hline 14 & Weight of healthy fruits per plant $(\mathrm{Kg})$ & 0.005 & $0.452 * *$ & 0.008 \\
\hline 15 & Weight of infested fruits per plant $(\mathrm{Kg})$ & 0.007 & $0.119 * *$ & 0.004 \\
\hline 16 & Total yield per plant $(\mathrm{Kg})$ & 0.068 & $0.590 * *$ & 0.048 \\
\hline 17 & Fruit yield per hectare (q/hac) & 3577.333 & $28410.440 * *$ & 2366.694 \\
\hline 18 & 100 seed weight $(\mathrm{g})$ & 0.003 & $0.022 * *$ & 0.001 \\
\hline
\end{tabular}

* Significant at 5\% level of probability ** Significant at $1 \%$ level of probability

Table.2 Analysis of variance for different yield attributing traits in brinjal for E2 season

\begin{tabular}{|c|c|c|c|c|}
\hline \multirow[t]{3}{*}{ S. N. } & \multirow[t]{3}{*}{ Characters } & \multicolumn{3}{|c|}{ Mean sum of squares } \\
\hline & & Replication & Genotype & Error \\
\hline & & 2 & 35 & 70 \\
\hline 1 & Days to first flowering & 13.406 & $178.868 * *$ & 10.566 \\
\hline 2 & Days to 50 percent flowering & 63.696 & $130.111^{* *}$ & 18.257 \\
\hline 3 & Days to first fruiting & 100.738 & $88.827 * *$ & 36.712 \\
\hline 4 & No. of Primary branches & 3.017 & $8.909 * *$ & 0.902 \\
\hline 5 & Plant height $(\mathrm{cm})$ & 7.961 & $409.453 * *$ & 7.971 \\
\hline 6 & Fruit length $(\mathrm{cm})$ & 2.184 & $81.139 * *$ & 1.919 \\
\hline 7 & Fruit diameter $(\mathrm{cm}$ & 0.202 & $6.328 * *$ & 0.653 \\
\hline 8 & Fruit index & 0.371 & $12.990 * *$ & 0.699 \\
\hline 9 & Average fruit weight (g) & 12.043 & $2310.978 * *$ & 15.047 \\
\hline 10 & No. of healthy fruits per plant & 0.658 & $55.363 * *$ & 0.637 \\
\hline 11 & No. of infested fruit per plant & 5.792 & $77.915 * *$ & 1.184 \\
\hline 12 & Total no. of fruit per plant & 41.296 & $231.045 * *$ & 6.224 \\
\hline 13 & Percent of shoot and fruit borer incidence & 16.727 & $1036.893 * *$ & 94.395 \\
\hline 14 & Weight of healthy fruits per plant $(\mathrm{Kg})$ & 0.002 & $0.073 * *$ & 0.002 \\
\hline 15 & Weight of infested fruits per plant $(\mathrm{Kg})$ & 0.022 & $0.122 * *$ & 0.001 \\
\hline 16 & Total yield per plant $(\mathrm{Kg})$ & 0.038 & $0.266^{* *}$ & 0.01 \\
\hline 17 & Fruit yield per hectare (q/hac) & 1883.139 & $13115.400 * *$ & 499.49 \\
\hline 18 & 100 seed weight $(\mathrm{g})$ & 0.003 & $0.024 * *$ & 0.001 \\
\hline
\end{tabular}

* Significant at $5 \%$ level of probability ** Significant at $1 \%$ level of probability 
Int.J.Curr.Microbiol.App.Sci (2018) 7(9): 1543-1552

Table.3 Estimation of coefficient of variation and other genetic parameter in brinjal for E1 season

\begin{tabular}{|c|c|c|c|c|c|c|c|c|}
\hline \multirow{2}{*}{$\begin{array}{l}\text { SI. } \\
\text { No. }\end{array}$} & \multirow[t]{2}{*}{ Characters } & \multirow{2}{*}{$\begin{array}{l}\text { General } \\
\text { mean }\end{array}$} & \multirow[t]{2}{*}{ Range } & \multicolumn{3}{|c|}{ Coefficient of variation } & \multirow{2}{*}{$\begin{array}{c}\text { Heritability } \\
(\%)\end{array}$} & \multirow{2}{*}{$\begin{array}{l}\text { G.A. as } \\
\% \\
\text { mean }\end{array}$} \\
\hline & & & & GCV\% & PCV\% & ECV\% & & \\
\hline 1 & $\begin{array}{l}\text { Days to first } \\
\text { flowering }\end{array}$ & 44.13 & $\begin{array}{c}35.26- \\
52.2\end{array}$ & 10.79 & 11.11 & 2.64 & 94.35 & 21.589 \\
\hline 2 & $\begin{array}{l}\text { Days to } 50 \text { percent } \\
\text { flowering }\end{array}$ & 50.84 & $\begin{array}{c}40.096- \\
61.46\end{array}$ & 10.75 & 11.09 & 2.71 & 94.02 & 21.481 \\
\hline 3 & $\begin{array}{l}\text { Days to first } \\
\text { fruiting }\end{array}$ & 56.05 & $\begin{array}{l}43.233- \\
65.433\end{array}$ & 9.72 & 10.19 & 3.04 & 91.11 & 19.118 \\
\hline 4 & $\begin{array}{l}\text { No. of Primary } \\
\text { branches }\end{array}$ & 10.19 & $\begin{array}{c}6.75- \\
14.486\end{array}$ & 19.69 & 22.75 & 11.4 & 74.88 & 35.091 \\
\hline 5 & Plant height (cm) & 136.92 & $\begin{array}{l}101.546- \\
164.993\end{array}$ & 9.29 & 10.07 & 3.89 & 85.06 & 17.559 \\
\hline 6 & Fruit length $(\mathbf{c m})$ & 14.26 & $\begin{array}{l}5.434- \\
34.24\end{array}$ & 37.99 & 39.19 & 9.6 & 93.99 & 75.875 \\
\hline 7 & $\begin{array}{l}\text { Fruit diameter } \\
(\mathbf{c m}\end{array}$ & 5.33 & $\begin{array}{l}2.933- \\
9.476\end{array}$ & 27.55 & 31.46 & 15.18 & 76.72 & 49.715 \\
\hline 8 & Fruit index & 3.09 & $\begin{array}{c}0.952- \\
11.67\end{array}$ & 69.087 & 71.989 & 20.53 & 92.1 & 136.63 \\
\hline 9 & $\begin{array}{ll}\text { Average } & \text { fruit } \\
\text { weight }(g) & \end{array}$ & 78.89 & $\begin{array}{l}48.952- \\
130.597\end{array}$ & 23.34 & 3.5 & 2.78 & 98.6 & 7.735 \\
\hline 10 & $\begin{array}{l}\text { No. of healthy } \\
\text { fruits per plant }\end{array}$ & 12.35 & $\begin{array}{l}3.153- \\
28.556\end{array}$ & 45.12 & 48.46 & 17.94 & 86.35 & 86.199 \\
\hline 11 & $\begin{array}{l}\text { No. of infested } \\
\text { fruit per plant }\end{array}$ & 5.49 & $\begin{array}{l}2.099- \\
11.483\end{array}$ & 41.68 & 46.61 & 20.87 & 79.96 & 76.778 \\
\hline 12 & $\begin{array}{l}\text { Total no. of fruit } \\
\text { per plant }\end{array}$ & 17.85 & $\begin{array}{l}7.424- \\
39.836\end{array}$ & 38.28 & 40.03 & 11.7 & 91.46 & 75.422 \\
\hline 13 & $\begin{array}{l}\text { Percent of shoot } \\
\text { and fruit borer } \\
\text { incidence }\end{array}$ & 32.09 & $\begin{array}{l}15.505- \\
78.453\end{array}$ & 39.63 & 42.751 & 25.17 & 85.935 & 75.68 \\
\hline 14 & $\begin{array}{l}\text { Weight of healthy } \\
\text { fruits per plant } \\
\text { (Kg) }\end{array}$ & 0.91 & $\begin{array}{c}0.233- \\
1.876\end{array}$ & 41.583 & 42.661 & 2.22 & 95.009 & 83.496 \\
\hline 15 & $\begin{array}{l}\text { Weight of infested } \\
\text { fruits per plant } \\
\text { Kg) }\end{array}$ & 0.39 & $\begin{array}{c}0.141- \\
0.992\end{array}$ & 48.738 & 51.07 & 21.24 & 90.977 & 95.763 \\
\hline 16 & $\begin{array}{l}\text { Total yield per } \\
\text { plant }(\mathrm{Kg})\end{array}$ & 1.31 & $\begin{array}{l}0.652- \\
2.437\end{array}$ & 32.481 & 36.578 & 16.91 & 78.854 & 59.417 \\
\hline 17 & $\begin{array}{l}\text { Fruit yield per } \\
\text { hectare }(\mathbf{q} / \mathbf{h a c})\end{array}$ & 288.38 & $\begin{array}{l}144.960- \\
541.663\end{array}$ & 33.97 & 37.97 & 16.95 & 80.06 & 61.123 \\
\hline 18 & 100 seed weight (g) & 0.34 & $\begin{array}{l}0.17- \\
0.58\end{array}$ & 24.935 & 26.193 & 9.27 & 90.629 & 48.901 \\
\hline
\end{tabular}


Table.4 Estimation of coefficient of variation and other genetic parameter in brinjal for

E2 season

\begin{tabular}{|c|c|c|c|c|c|c|c|c|}
\hline \multirow{2}{*}{$\begin{array}{l}\text { Sl. } \\
\text { No. }\end{array}$} & \multirow[t]{2}{*}{ Characters } & \multirow{2}{*}{$\begin{array}{c}\text { General } \\
\text { mean }\end{array}$} & \multirow[t]{2}{*}{ Range } & \multicolumn{3}{|c|}{ Coefficient of variation } & \multirow{2}{*}{$\begin{array}{c}\text { Herita } \\
\text { bility } \\
(\%)\end{array}$} & \multirow{2}{*}{$\begin{array}{c}\text { G.A. as } \\
\% \\
\text { mean }\end{array}$} \\
\hline & & & & $\begin{array}{c}\text { GCV } \\
\%\end{array}$ & $\begin{array}{c}\text { PCV } \\
\%\end{array}$ & $\begin{array}{c}\text { ECV } \\
\%\end{array}$ & & \\
\hline 1 & Days to first flowering & 58.8 & $43-75.436$ & 12.73 & 13.887 & 5.53 & 84.15 & 24.073 \\
\hline 2 & $\begin{array}{l}\text { Days to } 50 \text { percent } \\
\text { flowering }\end{array}$ & 117.44 & $98.2-129.666$ & 5.181 & 6.323 & 4.53 & 67.13 & 8.744 \\
\hline 3 & Days to first fruiting & 130.38 & $108.4-140.6$ & 3.19 & 5.641 & 4.65 & 32.12 & 3.732 \\
\hline 4 & $\begin{array}{l}\text { No. of Primary } \\
\text { branches }\end{array}$ & 7.17 & $3.873-11.546$ & 22.781 & 26.35 & 13.24 & 74.741 & 40.571 \\
\hline 5 & Plant height (cm) & 64.03 & $46.243-92.843$ & 18.066 & 18.596 & 4.41 & 94.379 & 36.155 \\
\hline 6 & Fruit length $(\mathrm{cm})$ & 13.54 & $5.087-29.74$ & 37.96 & 39.312 & 10.23 & 93.224 & 75.496 \\
\hline 7 & Fruit diameter (cm & 4.47 & $2.044-8.076$ & 30.772 & 35.688 & 18.08 & 74.345 & 54.657 \\
\hline 8 & Fruit index & 3.52 & $0.808-8.620$ & 56.078 & 60.673 & 23.74 & 85.427 & 106.772 \\
\hline 9 & Average fruit weight (g) & 71.97 & $21.14-133.273$ & 38.436 & 38.81 & 5.39 & 98.072 & 78.411 \\
\hline 10 & $\begin{array}{l}\text { No. of healthy fruits per } \\
\text { plant }\end{array}$ & 8.91 & $2.576-26.28$ & 47.961 & 48.75 & 8.96 & 96.627 & 97.067 \\
\hline 11 & $\begin{array}{l}\text { No. of infested fruit per } \\
\text { plant }\end{array}$ & 10.77 & $3.576-26.778$ & 46.961 & 48.036 & 10.11 & 95.574 & 94.575 \\
\hline 12 & $\begin{array}{l}\text { Total no. of fruit per } \\
\text { plant }\end{array}$ & 19.24 & $7.424-53.058$ & 44.993 & 46.824 & 12.97 & 92.332 & 89.062 \\
\hline 13 & $\begin{array}{l}\text { Percent of shoot and } \\
\text { fruit borer incidence }\end{array}$ & 57.18 & $\begin{array}{l}35.547- \\
146.489\end{array}$ & 31.614 & 34.912 & 16.99 & 76.896 & 55.302 \\
\hline 14 & $\begin{array}{l}\text { Weight of healthy fruits } \\
\text { per plant }(\mathrm{Kg})\end{array}$ & 0.53 & $0.188-0.852$ & 29.217 & 30.38 & 8.32 & 92.489 & 57.883 \\
\hline 15 & $\begin{array}{l}\text { Weight of infested fruits } \\
\text { per plant } \mathrm{Kg} \text { ) }\end{array}$ & 0.68 & $0.278-1.172$ & 29.292 & 29.651 & 4.59 & 97.597 & 59.612 \\
\hline 16 & $\begin{array}{l}\text { Total yield per plant } \\
(\mathrm{Kg})\end{array}$ & 1.2 & $0.581-1.782$ & 24.302 & 25.704 & 8.37 & 89.383 & 47.329 \\
\hline 17 & $\begin{array}{l}\text { Fruit yield per hectare } \\
\text { (q/hac) }\end{array}$ & 266.84 & $\begin{array}{c}129.183- \\
396.144\end{array}$ & 24.35 & 25.61 & 7.94 & 90.38 & 47.69 \\
\hline 18 & 100 seed weight (g) & 0.34 & $0.138-0.57$ & 25.779 & 26.992 & 7.99 & 91.218 & 50.72 \\
\hline
\end{tabular}

With the help of PCV and GCV alone it is not possible to determine the amount of variation which is heritable. The combination of high heritability along with high genetic advance will provide a clear base on the reliability of that particular trait in the selection of variable entries. In the present study broad sense heritability was found high for all the characters except for number of primary branches in both the season while for fruit diameter, days to $50 \%$ flowering and days to first fruiting in E2 season. In E1 season, the maximum estimates of heritability were recorded for average fruit weight (98.60) followed by weight of healthy fruits per plant (95.009), days to first flowering (94.35), days to $50 \%$ flowering (94.02), fruit length (93.99), fruit index (92.100), total number of fruits per 
plant (91.46), days to first fruiting (91.11),weight of infested fruits per plant (90.977), 100 seed weight (90.629), number of healthy fruits per plant (86.35), percent of shoot and fruit borer incidence (85.935), plant height (85.06), fruit yield per hectare (80.06), number of infested fruits per plant (79.96), total yield per plant (78.854) and fruit diameter (76.72). Whereas, in E2 season the maximum estimate of heritability was recorded for average fruit weight (98.072) followed by weight of infested fruits per plant (97.597), number of healthy fruits per plant (96.627), number of infested fruits per plant (95.574), plant height (94.379), fruit length (93.224), weight of healthy fruits per plant (92.489), total number of fruits per plant (92.332), 100 seed weight (91.218), fruit yield per hectare (90.38), total fruit yield per plant (89.383), fruit index (85.427), days to first flowering (84.15) and percent of shoot and fruit borer incidence (76.896). The high heritability estimates for these traits indicate that these characters are least influenced by the environment.

The genetic advance in a trait is an artifact of the heritability and selection differential expressed in terms of phenotypic standard deviation of the trait concerned and for comparison it is better to express the characters in terms of genetic advance as a percentage of mean. In the present study higher estimates of genetic advance as percentage of mean ( $>20 \%$ ) was observed for most of the characters under study in E1 season starting from fruit index (136.63) followed by weight of infested fruits per plant (95.763), number of healthy fruits per plant (86.199), weight of healthy fruits per plant (83.496), number of infested fruits per plant (76.778), fruit length (75.875), percent of shoot and fruit borer incidence (75.680), total number of fruits per plant (75.422), fruits yield per hectare (61.123), total fruits per plant (59.417), fruit diameter (49.715) 100 seed weight (48.901), average fruit weight (47.735), number of primary branches (35.091) days to first flowering (21.589), and days to $50 \%$ flowering (21.481). While for E2 season, fruit index (106.772) followed by number of healthy fruits per plant (97.067), number of infested fruits per plant (94.575), total number of fruits per plant (89.062), average fruit weight (78.411), fruit length (75.496), weight of infested fruits per plant (59.612), weight of healthy fruits per plant (57.883), percent of shoot and fruit borer incidence (55.302), fruit diameter (54.657), 100 seed weight (50.720), fruit yield per hectare (47.69), total yield per plant (47.329), number of primary branches (40.571), plant height (436.155) and days to first flowering (24.073) recorded the maximum estimates of genetic advance as percent of mean. High estimates of genetic advance as percentage of mean indicated that the preponderance of additive genetic effects in expression of these characters. Therefore, selection for these characters in segregating generations based on phenotypic performance would likely be more effective.

All the characters studied showed high to high, moderate to high or high to moderate values of heritability along with high genetic advance as a percent of mean except for days to 50 percent of flowering, number of primary branches, fruit diameter and days to first fruiting in E2 season showing low to low or moderate to low values of heritability along with low genetic advance. High heritability along with high genetic advance among the resulted traits indicate the predominant role of additive genetic component in expression of the traits hence, phenotypic selection will be rewarding for the further improvement of such traits. For different characters, similar results were also observed by various researchers like Chattopadhyay et al., (2011), Indiresh and Santhosha (2011), Thangavel et al., (2011), Dhaka and Soni (2012), Kumar et 
al., (2013a), Chaudhary and Kumar (2014), Mili et al., (2014), Gavade and Ghadage (2015), Patel et al., (2015), Tripathy et al., (2017) and Tirkey et al., (2018).

The present investigation on brinjal revealed the presence of substantial amount of exploitable variability in the material studied with respect to 18 yield attributing traits projecting, thereby, immense scope for genetic improvement through selection and hybridization. The study further elucidated that both non-additive and additive genetic component played the vital role in governing the expression of yield and its major components. Moderate to high GCV together with moderate to high heritability and genetic advance as per cent of mean was reported for majority of the characters under study which indicated predominant role of additive genetic component in the expression of these traits arising a chance of genetic improvement through phenotypic selection.

\section{References}

Ansari, S. F., Mehta, N., Ansari S. and Gavel, J. P. 2011. Variability studies in Brinjal (Solanum melongena L.) in Chhattisgarh plains. Electronic Journal of Plant Breeding, 2(2): 275-281.

Balaji, L., Reddy, P. S., Reddy, R. V. S. K. and Sivaraj, N. 2013. Variability, heritability and genetic advance studies in Brinjal (Solanum melongena L.). Electronic Journal of Plant Breeding, 4(1): 1097-1100.

Burton, G. W. and Devane, E. W. 1953. Estimating heritability in fall fescue (Festuca arundinacea) form replicated clonal material. Agronomy Journal, (4): 78-81.

Chattopadhyay, A., Dutta, S. and Hazra, P. 2011. Characterization of genetic resources and identification of selection indices of brinjal (Solanum melongena
L.) grown in Eastern India. Vegetable Crops Research Bulletin, 74: 39-49.

Chaudhary, P. and Kumar, S. 2014. Variability, heritability and genetic advance studies in eggplant (Solanum melongena L.). Plant Archives, 14(1): 483-486.

Chen, N. C. and Li, H. M. 1996. Cultivation and Seed Production of Eggplant. AVRDC, Annual Publication, 203(64): 246-261.

Choudhary B. 1976. Vegetables (4 ${ }^{\text {th }}$ ed.). National Boot Trust, New Delhi. Pp. 50-58.

Chourasia, H. K. and Shree, S. 2012. Genetic variability in quantitative characters of brinjal (Solanum melongena L.). Journal of Interacademicia, 16(2): 196202.

Dhaka, S. K. and Soni, A. K. 2012. Genetic variability in brinjal (Solanum melongena L.). The Asian Journal of Horticulture, 7(2): 537-540.

Gavade, R. T. and Ghadage, B. A. 2015. Genetic variability, heritability and genetic advance in segregating generation of Brinjal (Solanum melongena L.). Bioinfolet, 12(1C): 325328.

Indiresh, K. K. M. and Santhosha, H. M. 2011. Genetic variability in brinjal (Solanum melongena L.). Environment and Ecology, 29(3B): 1686-1688.

Johnson, H. W., Robinson, H. F. and Comstock. 1955. Estimates of genetic and environmental variability in soybean. J. Agric., 45: 478-481.

Kumar, S. R., Arumugam, T., Anandakumar, C. R., and Premalakshmi, V. 2013. Genetic variability for quantitative and qualitative characters in brinjal (Solanum melongena L.). African Journal of Agricultural Resources, 8(39): 4956-4959.

Madhavi, N., Mishra, A. C., Om Prasad, J., and Bahuguna, N. 2015. Studies on 
variability, heritability and genetic advance in brinjal (Solanum melongena L.). Plant Archives, 15(1): 277-281.

Mili, C., Bora, G. C., Das, B., and Paul, S. K. 2014. Studies on variability, heritability and genetic advance in brinjal (Solanum melongena L.) genotypes. Direct Research Journal of Agricultural and Food Science, 2(11): 192-194.

Mohammad, R. N. R., Mahdiyeh, P., Abdolrahim, G. and Javad, A. 2015. Variability, heritability and association analysis in eggplant (Solanum melongena). Journal of Agricultural and Biological Science, 10(12): 464 -468.

Nayak, B. R. and Nagre, P.K. 2013. Genetic variability and correlation studies in brinjal (Solanum melongena L.). Internat. J. Appl. Biol. \& Pharmaceut. Technol., 4(4): 211-215.

Panse, V. G. 1957. Genetics of quantitative characters in relation to plant breeding. Indian J. Genet., 17: 318-328.

Panse, V. G. and Shukhatme, P. V. 1967. Statistical Methods for Agricultural Workers. $2^{\text {nd }}$ ed. ICAR Publications Krishi Anusandhan Bhavan, Pusa, New Delhi-11001.

Patel, K., Patel, N. B., Patel, A. I., Rathod, H., and Patel, D. 2015. Study of variability, correlation and path analysis in brinjal (Solanum melongena L.). The bioscan, 10(4): 2037-2042.

Pujer, P., Jagadeesha, R. C., and Cholin, S. 2017. Genetic variability, heritability and genetic advance for yield, yield related components of brinjal (Solanum melongena L.) genotypes. Int. J. Pure App. Biosci., 5(5): 872-878.

Ravali, B. K., Reddy, R., Saidaiah, P. and Shivraj, N. 2017. Variability, Heritability and Genetic advance in brinjal (Solanum melongena L.). International Journal of Current
Microbiology and Applied Sciences, 6(6): 42-47.

Reshmika, P. K., Gasti, V. D., Evoor, S., Jayappa, J. and Mulge, R. 2015. Genetic variability studies for growth, earliness, yield and quality parameters in brinjal (Solanum melongena L.). Environment \& Ecology, 33 (2): 761-766.

Sato, Y., Itagaki, S., Kurokawa, T., Ogura, J., Kobayashi, M., Hirano, T., Sugawara, M. and Iseki, K. 2011. In vitro and in vivo antioxidant properties of chlorogenic acid and caffeic acid. International Journal of Pharmaceutics, 403:136-138.

Shekar, K. C., Ashok. P. and Sasikala, K. 2012. Studies on heritability and multivariate analyses in brinjal (Solanum melongena L.) Vegetable crops resource Bulletin, 76: 79-88.

Shende, K. G., Birajdar, U. M., Bhalekar, M. N. and Patil, B. T. 2014. Correlation and path analysis in eggplant (Solanum melongena L.). South Indian Horticulture Journal, 39(1): 108-110.

Singh, O., Singh, B., Singh, K. V., Chand, P. and Vaishali. 2013. Studies on genetic variability in brinjal (Solanum Melongena L.). Annals of Horticulture, 6(2): 279-283.

Sujin, G. S., Karuppaiah, P. and Saravanan, K. 2017. Genetic variability and correlation studies in brinjal (Solanum melongena L.). Indian Journal of Agricultural Resource, 51(2): 112-119.

Thangavel, P., Thirugnanakumar, S. and Baradhan, G. 2011. Studies on genetic variability, heritability and genetic advance in segregating generations of brinjal (Solanum melongena L.). Plant Archives, 11(1): 453-456.

Tirkey, M., Saravana, S and Pushpa lata. 2018. Studies on variability, heritability and genetic advance for yield and its attributes in brinjal (Solanum melongena L.). Journal of 
Pharmacognosy and Phytochemistry, 1181-1183

Tripathy, B., Dhananjay, S., Jangde, B. P. and Bairwa, P. L. 2017. Genetic variability and heritability studies in brinjal (Solanum melongena L.). Journal of Pharmacognosy and Phytochemistry, 10: 109-116.

Vidhya, C. and Kumar, N. 2015. Genetic variability studies in Brinjal (Solanum melongena) for fruit yield and quality. Electronic Journal of Plant Breeding, 6(3): 668-671
Vidhya, C. and Kumar, N. 2015. Genetic variability studies in Brinjal (Solanum melongena) for fruit yield and quality. Electronic Journal of Plant Breeding, 6(3): 668-671

Weber, C. R. and Moorthy, H. R. 1952. Heritable and non- heritable relationship and variability of oil content and agronomic characters in the $F_{2}$ generation of soyabean crosses. Agronomy Journal, 44: 202-209.

\section{How to cite this article:}

Priyanka Verma, M.L. Kushwaha and Ankit Panchbhaiya. 2018. Studies on Variability, Heritability and Genetic Advance for Yield Attributing Traits in Brinjal (Solanum melongena L.) for Two Different Seasons. Int.J.Curr.Microbiol.App.Sci. 7(09): 1543-1552. doi: https://doi.org/10.20546/ijcmas.2018.709.185 